\title{
Marinilactibacillus piezotolerans sp. nov., a novel marine lactic acid bacterium isolated from deep sub-seafloor sediment of the Nankai Trough
}

\author{
Laurent Toffin, ${ }^{1} \dagger$ Klaus Zink, ${ }^{2}$ Chiaki Kato, ${ }^{3}$ Patricia Pignet, ${ }^{4}$ \\ Adeline Bidault, ${ }^{1}$ Nadège Bienvenu, ${ }^{1}$ Jean-Louis Birrien ${ }^{1}$ \\ and Daniel Prieur ${ }^{1}$
}

Correspondence Laurent Toffin toffin@jamstec.go.jp

\begin{abstract}
${ }^{1}$ UMR 6539, Centre National de la Recherche Scientifique et Université de Bretagne Occidentale, Technopôle Brest-Iroise, Place Nicolas Copernic, F-29280 Plouzané, France
\end{abstract}

${ }^{2}$ GeoForschungsZentrumPotsdam (GFZ), Telegrafenberg, D-14473 Potsdam, Germany

${ }^{3}$ Extremobiosphere Research Centre, Japan Agency for Marine-Earth Science and Technology (JAMSTEC), 2-15 Natsushima-cho, Yokosuka 237-0061, Japan

${ }^{4}$ Laboratoire de Microbiologie et de Biotechnologie des Extrêmophiles, Département de Valorisation des Produits, IFREMER, Centre de Brest, BP 70, F-29280 Plouzané, France

\begin{abstract}
A piezotolerant, mesophilic, marine lactic acid bacterium (strain $L T 20^{\top}$ ) was isolated from a deep sub-seafloor sediment core collected at Nankai Trough, off the coast of Japan.

Cells were Gram-positive, rod-shaped, non-sporulating and non-motile. The $\mathrm{NaCl}$ concentration range for growth was $0-120 \mathrm{~g} \mathrm{I}^{-1}$, with the optimum at $10-20 \mathrm{~g} \mathrm{I}^{-1}$. The temperature range for growth at $\mathrm{pH} 7 \cdot 0$ was $4-50^{\circ} \mathrm{C}$, with the optimum at $37-40^{\circ} \mathrm{C}$. The optimum $\mathrm{pH}$ for growth was $7 \cdot 0-8 \cdot 0$. The optimum pressure for growth was $0 \cdot 1 \mathrm{MPa}$ with tolerance up to $30 \mathrm{MPa}$. The main cellular phospholipids were phosphatidylglycerols (25\%), diphosphatidylglycerols (34\%) and a group of compounds tentatively identified as ammonium-containing phosphatidylserines (32\%); phosphatidylethanolamines ( $9 \%$ ) were minor components. The fatty acid composition was dominated by side chains of $16: 0,14: 0$ and $16: 1$. The $G+C$ content of the genomic DNA was 42 mol\%. On the basis of $16 \mathrm{~S}$ rRNA gene sequence analysis and the secondary structure of the V 6 region, this organism was found to belong to the genus Marinilactibacillus and was closely related to Marinilactibacillus psychrotolerans M13-2 ${ }^{\top}$ (99\%), Marinilactibacillus sp. strain MJYP.25.24 (99\%) and Alkalibacterium olivapovliticus strain ww2-SN4C (97\%). Despite the high similarity between their 16S rRNA gene sequences (99\%), the DNA-DNA hybridization levels were less than $20 \%$. On the basis of physiological and genetic characteristics, it is proposed that this organism be classified as a novel species, Marinilactibacillus piezotolerans sp. nov. The type strain is $\mathrm{LT}^{2} 0^{\top}\left(=\mathrm{DSM} 16108^{\top}=\mathrm{JCM} 12337^{\top}\right)$.
\end{abstract}

The occurrence of a deep bacterial biosphere in marine sediments to more than $800 \mathrm{~m}$ below the sea floor (Parkes et al., 2000) has raised questions about what types of bacteria inhabit deeply buried sediments. Populations of viable micro-organisms have been found in deep marine deposits, but studies have focused on sulphate-reducers (Bale et al.,

tPresent address: Extremobiosphere Research Centre, JAMSTEC, 2-15 Natsushima-cho, Yokosuka 237-0061, Japan.

Abbreviation: PLFA, phospholipid fatty acid.

The GenBank/EMBL/DDBJ accession number for the 16S rRNA gene sequence of Marinilactibacillus piezotolerans $\mathrm{LT}^{2} \mathrm{O}^{\top}$ is AY485792.

Details of the morphology, differential phenotypic characteristics and the effect of $\mathrm{pH}$ on glucose fermentation in strain $\mathrm{LT}^{\mathrm{T}} \mathrm{O}^{\mathrm{T}}$ are available as supplementary material in IJSEM Online.
1997) and methanogens (Mikucki et al., 2003). Recently, however, autotrophic and heterotrophic bacteria belonging to the phyla Firmicutes, Cytophaga, Spirochaetes and Proteobacteria have been enriched from deep sediments of the Nankai Trough south-east of Japan (Toffin et al., 2004a, b). In near-surface deep marine sediments, fermentative micro-organisms could play a significant role in the transformation of organic matter. At present, little is known about the origin and the adaptation of viable fermentative micro-organisms in such deep environments. To date, only a few types of lactic acid bacteria have been isolated from marine environments (Franzmann et al., 1991), such as the two species from Ace Lake in Antarctica, namely Carnobacterium fundicum and Carnobacterium alterfundicum (Spielmeyer et al., 1993). Recently, the fermentative 
marine lactic acid bacterium Marinilactibacillus psychrotolerans was isolated from dead and living marine organisms at Miura Peninsula in Japan (Ishikawa et al., 2003). In addition, members of the genus Marinilactibacillus have been isolated from coastal sub-seafloor sediments of the Okhotsk Sea (Inagaki et al., 2003) and Carnobacterium-like sequences have been retrieved from Nankai Trough (Newberry et al., 2004). At present, the genus Marinilactibacillus comprises only one species, $M$. psychrotolerans, which has developed some adaptations to salt, temperature and $\mathrm{pH}$. This species is also able to ferment a wide range of organic substrates, producing lactic acid as the main end product of metabolism.

M. psychrotolerans strain M13-2 ${ }^{\mathrm{T}}\left(=\mathrm{IAM} 14980^{\mathrm{T}}\right)$ was used as a reference strain. This strain was obtained from the IAM culture collection, Institute of Molecular and Cellular Biosciences (Tokyo University, Japan).

The novel isolate was obtained from a sediment core collected at $4 \cdot 15 \mathrm{~m}$ below the sea floor from a water depth of $4790.7 \mathrm{~m}$ in the Pacific Ocean at Nankai Trough, off the coast of Japan (site 1173: $32^{\circ} 14 \cdot 7^{\prime} \mathrm{N} 135^{\circ} 1 \cdot^{\prime} 5^{\prime} \mathrm{E}$ ) between 28 May and 7 June 2000 (Ocean Drilling Program, Leg 190). All details of the environmental conditions, sampling and sub-sampling procedures have been previously reported (Cragg et al., 1992a, b; Parkes et al., 1995; Moore et al., 2001; Toffin et al., 2004a).

Cultures were enriched anaerobically in $50 \mathrm{ml}$ vials containing $10 \mathrm{ml}$ medium $\mathrm{MM}$, which consisted of the following $\left(1^{-1}\right.$ distilled water): $23 \mathrm{~g} \mathrm{NaCl}, 3 \mathrm{~g} \mathrm{MgCl} 2 \cdot 6 \mathrm{H}_{2} \mathrm{O}, 4 \mathrm{~g}$ $\mathrm{Na}_{2} \mathrm{SO}_{4}, 0.7 \mathrm{~g} \mathrm{KCl}, 0.15 \mathrm{~g} \mathrm{CaCl}_{2}, 0.5 \mathrm{~g} \mathrm{NH}_{4} \mathrm{Cl}, 0.27 \mathrm{~g}$ $\mathrm{KH}_{2} \mathrm{PO}_{4}, 15 \mathrm{ml} 1 \mathrm{M} \mathrm{NaHCO}, 0 \cdot 1$ g yeast extract (Difco), $1 \mathrm{ml}$ trace elements (Widdel \& Bak, 1992), $1 \mathrm{ml}$ vitamin solution (Widdel \& Bak, 1992), $1 \mathrm{ml}$ thiamine $(0.01 \%$, w/v; Widdel \& Bak, 1992), $1 \mathrm{ml}$ vitamin $\mathrm{B}_{12}(0.005 \%$, w/v; Widdel \& Bak, 1992), $1.0 \mathrm{~g}$ sodium acetate, $2 \cdot 0 \mathrm{~g}$ monomethylamine, $5 \cdot 0$ g sodium formate, $0.5 \%(\mathrm{v} / \mathrm{v})$ methanol and $0.5 \mathrm{mg}$ resazurin. The $\mathrm{pH}$ of the medium was adjusted to $7 \cdot 2$ at room temperature before autoclaving. Sterile medium was reduced by adding $0 \cdot 5 \mathrm{~g}$ sodium sulphide $\mathrm{l}^{-1}$ and then distributed into serum vials before inoculation. Cultures were incubated at $25^{\circ} \mathrm{C}$ in the dark. Growth of lemon-shaped, coccoid, vibrio-shaped, long rod-shaped and short rod-shaped cells was observed in enrichment cultures after 2 days incubation. Positive enrichments were subcultured into the same medium under anaerobic conditions. Once stable enrichment cultures had been established, subsequent enrichment cultures were grown on agar plates ( $1 \%$, w/v; Difco), incubated anaerobically at $25^{\circ} \mathrm{C}$. Small, translucent, round colonies around $1 \mathrm{~mm}$ in diameter were visible after 3 days and one colony was randomly picked. The dilution to extinction technique, followed by repeated streaking onto plates, was employed to obtain pure culture. The isolate was designated strain $\mathrm{LT} 20^{\mathrm{T}}$ $\left(=\right.$ DSM $\left.16108^{\mathrm{T}}=\mathrm{JCM} 12337^{\mathrm{T}}\right)$ and the purity of the isolate was checked by means of microscopic observations and by cloning and sequencing five independent 16S rRNA gene clones.

Isolate LT $20^{\mathrm{T}}$ was routinely grown in YPG medium containing the following $\left(\mathrm{l}^{-1}\right.$ distilled water): $25 \mathrm{~g} \mathrm{NaCl}, 3 \mathrm{~g}$ $\mathrm{MgCl}_{2}, 0.5 \mathrm{~g} \mathrm{KCl}, 4 \mathrm{~g} \mathrm{Na}_{2} \mathrm{SO}_{4}, 2$ g glucose, 5 g yeast extract (Difco), $5 \mathrm{~g}$ peptone (Difco), 34.6 g PIPES and $0.05 \mathrm{~g}$ $\mathrm{KH}_{2} \mathrm{PO}_{4}$. The $\mathrm{pH}$ of the medium was adjusted to $7 \cdot 2$ before autoclaving. Unless indicated otherwise, cultures were incubated aerobically at $37^{\circ} \mathrm{C}$ with shaking. Stock cultures of isolate LT $20^{\mathrm{T}}$ were stored in culture medium at $4{ }^{\circ} \mathrm{C}$. For long-term storage, pure cultures were stored at $-80{ }^{\circ} \mathrm{C}$ in the same medium containing $20 \%(\mathrm{w} / \mathrm{v})$ glycerol.

Growth was monitored by measuring changes in turbidity at $600 \mathrm{~nm}$ using a Spectronic 401 spectrophotometer (Spectronic Instruments). Direct cell counts were determined on samples fixed with $2 \%(\mathrm{v} / \mathrm{v})$ glutaraldehyde for $1 \mathrm{~h}$ at $4{ }^{\circ} \mathrm{C}$ by using a counting chamber (depth $0.02 \mathrm{~mm}$; Thoma). An Olympus CX40 microscope was used routinely to observe the cells. For negative staining, $20 \mu \mathrm{l}$ bacterial suspension fixed with $2 \%(\mathrm{w} / \mathrm{v})$ glutaraldehyde was dropped onto a carbon-coated copper grid (Nishin $\mathrm{EM})$. A droplet of a $1 \%(\mathrm{w} / \mathrm{v})$ neutral phosphotungstic acid solution ( $\mathrm{pH} 7 \cdot 6$ ) was added to the carbon grid for $40 \mathrm{~s}$ and excess liquid was removed. Specimens were air-dried and electron micrographs taken using a JEOL electron microscope (JEM 1210). Gram staining, catalase, oxidase, gelatinase and amylase $(1 \%, \mathrm{w} / \mathrm{v})$ reactions were tested with cells grown in YPG medium.

Cells of strain $\mathrm{LT} 20^{\mathrm{T}}$ were straight to slightly curved rodshaped cells approximately $2-2 \cdot 2 \mu \mathrm{m}$ in length and $0 \cdot 3-$ $0.35 \mu \mathrm{m}$ wide (see the transmission electron micrograph available as a supplementary figure in IJSEM Online), but were slightly elongated in older cultures. They occurred singly, in pairs or in small chains at $37^{\circ} \mathrm{C}$ and stained Grampositive. The cells were non-motile. Endospores or spores were not observed and cells were catalase-positive and oxidase-negative.

To determine the optimum temperature, $\mathrm{pH}$ and $\mathrm{NaCl}$, cells were grown in aerobic tubes $(15 \mathrm{ml})$ containing $5 \mathrm{ml} \mathrm{YPG}$ medium with shaking (130 r.p.m.) as reported previously (Toffin et al., 2004b). To determine the effect of $\mathrm{pH}$ on growth, YPG medium was modified with the following

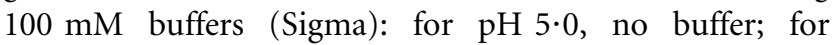
pH 5.5 and $6 \cdot 0$, MES buffer; for $\mathrm{pH} 6.5$ and $7 \cdot 0$, PIPES buffer; for $\mathrm{pH} 7 \cdot 5$, HEPES buffer; for $\mathrm{pH} 8 \cdot 0$ and $8 \cdot 5$, Tris buffer; for $\mathrm{pH} 9 \cdot 0,10 \cdot 0$ and $11 \cdot 0$, no buffer.

The effect of hydrostatic pressure on growth rates of strain $\mathrm{LT} 20^{\mathrm{T}}$ was determined at $0 \cdot 1,10,20,30,40$ and $50 \mathrm{MPa}$ at $37^{\circ} \mathrm{C}$ as previously described (Kato et al., 1995).

The ability of strain LT20 ${ }^{\mathrm{T}}$ to utilize single carbon sources was investigated by adding one of the following organic compounds to the modified YPG medium, from which carbon sources were omitted: formate $(30 \mathrm{mM})$, pyruvate 
$(20 \mathrm{mM})$, propionate $(20 \mathrm{mM})$, butyrate $(10 \mathrm{mM})$, isobutyrate $(5 \mathrm{mM})$, 2-methyl butyrate $(5 \mathrm{mM})$, 3-methyl butyrate $(5 \mathrm{mM})$, valerate $(5 \mathrm{mM})$, isovalerate $(5 \mathrm{mM})$, glutamate $(5 \mathrm{mM})$, caproate $(5 \mathrm{mM})$, malate $(10 \mathrm{mM})$, succinate $(10 \mathrm{mM})$, heptanoate $(5 \mathrm{mM})$, acetate $(15 \mathrm{mM})$, lactate $(20 \mathrm{mM})$, caprylate $(2.5 \mathrm{mM})$, monomethylamine $(0 \cdot 2 \%, \mathrm{w} / \mathrm{v})$, propanol $(5 \mathrm{mM})$, ethanol $(0 \cdot 2 \%, \mathrm{w} / \mathrm{v})$ and peptone, tryptone, L-arabinose, cellobiose, fructose, galactose, lactose, maltose, D-mannitol, mannose, L-rhamnose, D-sorbitol, sucrose, xylose, glucose (each at $0 \cdot 2 \%, \mathrm{w} / \mathrm{v}$ ). Strain $\mathrm{LT} 20^{\mathrm{T}}$ was additionally characterized by using the identification system API 20E (bioMérieux) at $37^{\circ} \mathrm{C}$ according to the manufacturer's instructions.

The ability of the isolate to grow in the presence of different electron acceptors was tested on YP medium (Toffin et al., $2004 \mathrm{~b})$ containing maltose $(0 \cdot 2 \%, \mathrm{w} / \mathrm{v})$ and yeast extract $(0.01 \%, w / v)$. The following electron acceptors were tested: elemental sulphur and L-cystine, each at $1 \%(\mathrm{w} / \mathrm{v})$; thiosulphate, sulphate, nitrate and nitrite, each at $20 \mathrm{mM}$. The aerobic headspace in each case was replaced with $\mathrm{N}_{2}$ $(100 \%, 100 \mathrm{kPa})$. Preparation of amorphous Fe(III) oxide and $\mathrm{Fe}(\mathrm{II})$ determination were performed as described by Slobodkin et al. (1999). For nitrite and ammonium analysis, cultures were grown anaerobically in modified YP medium supplemented with $5 \mathrm{mM} \mathrm{KNO}_{3}$ and under an atmosphere of $\mathrm{N}_{2}$.

Fermentation products from the sugars glucose, ribose, xylose, fructose, cellobiose, maltose, sucrose, mannitol, adonitol, L-arabinose, D-arabinose, galactose, lactose, melezitose, glycerol, sorbitol and starch were tested (each at $0 \cdot 2 \%, \mathrm{w} / \mathrm{v})$. Additional analysis of fermentation end products formed from glucose at different $\mathrm{pH}$ values was performed in modified YPG medium in which the buffer was replaced by $100 \mathrm{mM}$ HEPES (Sigma) and adjusted to $\mathrm{pH} 7 \cdot 0,8 \cdot 0$ and $9 \cdot 0$ to minimize the $\mathrm{pH}$ decrease in media during cultivation.

The organic acid metabolic end products during fermentation and electron-acceptor tests were analysed by using HPLC (Alliance 2690; Waters) as described by Wery et al. (2001).

Reduction of nitrate and nitrite was determined by using the indophenol blue method of Koroleff (1969) and Solorzano (1969). $\mathrm{H}_{2} \mathrm{~S}$ production was evaluated as described elsewhere (Jeanthon et al., 2002).

Strain $\mathrm{LT} 20^{\mathrm{T}}$ is a facultatively anaerobic and obligately heterotrophic bacterium. The isolate was able to grow on various substrates tested as sole carbon sources with $\mathrm{O}_{2}$ as electron acceptor, as revealed by lactic acid production. Peptone, tryptone, cellobiose, fructose, galactose, lactose, maltose, mannitol, sorbitol, sucrose, xylose and glucose were used as sole carbon sources, but formate, pyruvate, propionate, butyrate, isobutyrate, 2-methyl butyrate, 3methyl butyrate, valerate, isovalerate, glutamate, caproate, malate, succinate, heptanoate, caprylate, acetate, lactate, monomethylamine, propanol, ethanol, L-arabinose, mannose and L-rhamnose were not.

The end products of a wide range of sugar fermentations were determined: lactic acid was produced as an end product with acetate, formate and ethanol (see the phenotypic characterization available as a supplementary table in IJSEM Online); at $\mathrm{pH} 7 \cdot 0$, lactate was strongly produced from glucose, D-xylose, D-fructose and D-mannitol, with some traces of formate, acetate and ethanol produced at various molar ratios depending on the substrate. The effect of $\mathrm{pH}$ on glucose fermentation was also investigated (see the data available as a supplementary table in IJSEM Online) and, despite the use of buffered media, lactic acid production correlated with $\mathrm{pH}$ decrease. During growth, $\mathrm{pH}$ values decreased by $0 \cdot 3-0 \cdot 5 \mathrm{pH}$ units from the initial $\mathrm{pH}$ with buffered media. During the course of glucose fermentation at $\mathrm{pH} 9.0$ using buffered medium, the $\mathrm{pH}$ decreased and $0.96 \mathrm{~mol}$ lactate was produced per mol glucose consumed (see the data available as a supplementary table in IJSEM Online). When the initial pH increased from $7 \cdot 0$ to $9 \cdot 0$, production of lactate increased, while formate, acetate and ethanol decreased, as reported previously for other lactic acid bacteria (Rhee \& Pack, 1980; Franzmann et al., 1991; Janssen et al., 1995; Ishikawa et al., 2003).

Growth was observed between $0 \cdot 1$ and $30 \mathrm{MPa}$ at $37^{\circ} \mathrm{C}$, but no growth was observed at $40 \mathrm{MPa}$. The growth rates of the isolate under high-pressure conditions were comparable with those at atmospheric pressure $\left(1 / t_{\mathrm{d}}=0.3\right.$ at $0.1 \mathrm{MPa}$, 0.28 at $10 \mathrm{MPa}, 0.26$ at $20 \mathrm{MPa}$ and 0.25 at $30 \mathrm{MPa}$ ).

Respiratory quinones were extracted using methanol/ hexane (Toffin et al., 2004b). It was observed that respiratory quinones could not be detected in strain $\mathrm{LT} 20^{\mathrm{T}}$.

For phospholipid and phospholipid fatty acid (PLFA) analysis of strains $\mathrm{LT} 20^{\mathrm{T}}$ and M13-2 ${ }^{\mathrm{T}}$, a modified method of Zink et al. (2003) was used. The lipid content of culture samples was extracted by flow-blending (Radke et al., 1978) using methanol/dichloromethane $(1: 2, \mathrm{v} / \mathrm{v})$. Distearoyl$\mathrm{D}_{70}$-phosphatidylcholine (molecular mass $860 \cdot 6 \mathrm{Da}$ ) and palmitoyl- $\mathrm{D}_{31}$-lysophosphatidylcholine $(526.82 \mathrm{Da})$ were added as internal standards. The total extract was rinsed with water to remove water-soluble compounds; therefore, methanol and water (dichloromethane/methanol/water; 1:1:0.9 by vol.) were added for phase separation. Total lipids were obtained from the lower organic phase.

The extract was separated to give four fractions of different polarity modified according to Zink et al. (2003). Half of the fraction containing the intact phospholipids was analysed by LC-MS. The second aliquot was used for mild alkaline hydrolysis, as described by White et al. (1979), to obtain PLFAs, which were analysed, as their methyl esters, by using GC-MS.

Strain $\mathrm{LT} 20^{\mathrm{T}}$ contains four different classes of phospholipids: phosphatidyldiacylglycerols (25\% of total), 
diphosphatidyldiacylglycerols (34\%), tentatively identified phosphatidyldiacylserines (32\%) and phosphatidyldiacylethanolamines $(9 \%)$. It is noteworthy that the phosphatidyldiacylserines had an additional ammonium group linked to the head group, this being corroborated by LCMS-MS analysis. The PLFAs obtained from GC-MS had chain lengths in the range $\mathrm{C}_{12}-\mathrm{C}_{19}$, the most abundant being saturated $\mathrm{C}_{16}(44 \cdot 72 \%)$, saturated $\mathrm{C}_{14}(31 \cdot 45 \%)$ and unsaturated $\mathrm{C}_{16}(17 \cdot 11 \%)$ fatty acids (Table 1$)$. Unsaturated fatty acids only occurred as monounsaturated moieties (Table 1).

The PLFA distribution determined by GC-MS analysis corresponds with the fatty acyl side-chain composition of intact phospholipids determined by LC-MS.

The distribution of the PLFAs of strain $\mathrm{LT} 20^{\mathrm{T}}$ reflects a common pattern for bacterial organisms with $\mathrm{C}_{16: 0}$ and $\mathrm{C}_{14: 0}$ as the predominant fatty acids. Thus, no significant adaptation to environmental conditions can be deduced from the PLFA composition alone. The PLFA distribution of M. psychrotolerans M13-2 ${ }^{\mathrm{T}}$, with $\mathrm{C}_{18: 1}, \mathrm{C}_{16: 0}, \mathrm{C}_{16: 1}$ and $\mathrm{C}_{18: 0}$ as the dominant fatty acids, differs significantly from the PLFA pattern of strain $\mathrm{LT} 20^{\mathrm{T}}$ (Table 1) but corresponds with the findings of Ishikawa et al. (2003).

For determination of the $\mathrm{G}+\mathrm{C}$ content, DNA was isolated after disruption of cells using a French pressure cell and then purified on hydroxyapatite (Cashion et al., 1977). The DNA

Table 1. Relative distribution of PLFAs of M. piezotolerans sp. nov. $\mathrm{LT}_{20}{ }^{\mathrm{T}}$ and M. psychrotolerans $\mathrm{M} 13-2^{\mathrm{T}}$

Fatty acids are listed in order of elution and values are percentages of total fatty acids, measured as fatty acid methyl esters by using GC-MS. -, Not detected.

\begin{tabular}{|lcc|}
\hline Fatty acid & LT20 $^{\mathbf{T}}$ & $\mathbf{M 1 3 - 2}^{\mathbf{T}}$ \\
\hline $\mathrm{C}_{12: 0}$ & $0 \cdot 81$ & $0 \cdot 24$ \\
$\mathrm{C}_{14: 1}$ & $2 \cdot 48$ & $0 \cdot 32$ \\
$\mathrm{C}_{14: 0}$ & $31 \cdot 45$ & $2 \cdot 43$ \\
$\mathrm{C}_{15: 0}$ & $0 \cdot 09$ & $0 \cdot 24$ \\
$\mathrm{~S}^{*}$ & & \\
$\mathrm{C}_{16: 1}$ & $14 \cdot 09$ & $12 \cdot 11$ \\
$\mathrm{C}_{16: 1}$ & $3 \cdot 02$ & $2 \cdot 08$ \\
$\mathrm{C}_{16: 0}$ & $44 \cdot 72$ & $31 \cdot 18$ \\
cyclo $\mathrm{C}_{17: 0}$ or $\mathrm{C}_{17: 1}$ & $1 \cdot 42$ & - \\
$\mathrm{C}_{17: 0}$ & - & $0 \cdot 14$ \\
$\mathrm{~S}_{2}$ & & $38 \cdot 49$ \\
$\mathrm{C}_{18: 1}$ & $0 \cdot 19$ & $1 \cdot 67$ \\
$\mathrm{C}_{18: 1}$ & & $8 \cdot 18$ \\
$\mathrm{C}_{18: 0}$ & $0 \cdot 75$ & - \\
cyclo $\mathrm{C}_{19: 0}$ or $\mathrm{C}_{19: 1}$ & $0 \cdot 98$ & $2 \cdot 92$ \\
$\mathrm{C}_{20: 1}$ & - & \\
\hline
\end{tabular}

${ }^{*}$ S1 and S2 are deuterium-labelled fatty acids from standard phospholipids. S1 is from palmitoyl- $\mathrm{D}_{31}$-lysophosphatidylcholine and S2 is from distearoyl- $\mathrm{D}_{70}$-phosphatidylcholine. was hydrolysed with P1 nuclease and the nucleotides were dephosphorylated with bovine alkaline phosphatase (Mesbah et al., 1989). The G $+\mathrm{C}$ content of the genomic DNA of strain $\mathrm{LT} 20^{\mathrm{T}}$ was determined by using HPLC according to the method described by Tamaoka \& Komagata (1984) as $42 \cdot 0 \mathrm{~mol} \%$.

Genomic DNA of strain LT2 $20^{\mathrm{T}}$ for $16 \mathrm{~S}$ rRNA gene sequence analysis and DNA-DNA hybridization was isolated by using the procedure described by Erauso et al. (1992). The complete 16S rRNA gene sequence of strain LT20 ${ }^{\mathrm{T}}$ was determined as previously reported by Toffin et al. (2004b). Phylogenetic analysis was performed using the software package ARB (Ludwig et al., 2004). The 16S rRNA gene sequence was aligned with FastAligner version 3.0 and aligned manually with sequences of representative related genera obtained from the Ribosomal Database Project (Maidak et al., 2001) or from recent GenBank releases. The secondary structure was used as a guide to ensure that only homologous regions were compared. Phylogenetic trees were constructed using the neighbour-joining method (Saitou \& Nei, 1987) with the Jukes-Cantor correction factor (Jukes \& Cantor, 1969). The topologies of the trees were evaluated by using maximum parsimony (Lake, 1987) and maximum likelihood (Felsenstein, 1981). A bootstrap test of 1000 replicates was used to identify solid branches and establish a confidence level for each node (Felsenstein, 1985).

The 16S rRNA gene sequence analysis placed strain LT20 ${ }^{\mathrm{T}}$ as a close relative of M. psychrotolerans $\mathrm{M} 13-2^{\mathrm{T}}$ (Fig. 1). According to $16 \mathrm{~S}$ rRNA gene sequences, a similarity matrix generated using the correction of Jukes \& Cantor (1969) revealed that strain $\mathrm{LT}_{2} 0^{\mathrm{T}}$ was $99 \%$ similar to M. psychrotolerans strain $\mathrm{M} 13-2^{\mathrm{T}}$ isolated from living and decomposing marine organisms collected from temperate and subtropical areas in Japan (Ishikawa et al., 2003), $99 \%$

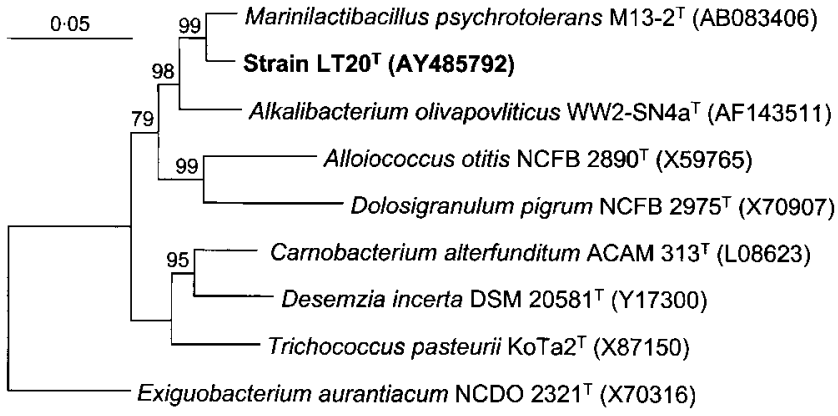

Fig. 1. Phylogenetic relationships of $M$. piezotolerans sp. nov. $\mathrm{LT}_{2} \mathrm{O}^{\top}$ and other lactic acid bacteria produced by neighbourjoining. The sequence of the small-subunit RNA of strain $L T 20^{\top}$ was aligned with other 16S rRNA sequences from the RDP and GenBank. Numbers at branch nodes are bootstrap values based on 1000 bootstrap resamplings. This topology was confirmed by maximum-parsimony and maximum-likelihood methods. Bar, 0.05 expected changes per sequence position. 
similar to Marinilactibacillus sp. strain OHKMJYP.25.24, isolated from sub-seafloor sediment of the Okhotsk Sea (Inagaki et al., 2003), and $96.5 \%$ similar to Alkalibacterium olivapovliticus, isolated from edible-olive washwaters (Ntougias \& Russell, 2001). Bootstrap values using distance matrices placed strain $\mathrm{LT} 20^{\mathrm{T}}$ with $M$. psychrotolerans $\mathrm{M} 13-2^{\mathrm{T}}$ with $99 \%$ bootstrap resampling (Fig. 1 ). The predicted secondary structure of the V6 region of the $16 \mathrm{~S}$ rRNA gene of the novel isolate was compared with those of $M$. psychrotolerans and other related genera and was found to belong to the genus Marinilactibacillus and to differ from the others as suggested by Ishikawa et al. (2003).

Levels of genetic relatedness were determined by performing DNA-DNA dot-blot hybridization experiments, as previously reported, with modifications (Marteinsson et al., 1995). Probe DNA was labelled by using an Enhanced ChemiFluorescence random prime labelling kit (fluoresceinlabelled DNA probe; Amersham International). The level of DNA-DNA hybridization is the mean level of binding for at least four replicates. No significant relatedness $(<20 \%)$ was obtained between bulk cellular DNA of isolate LT2 $0^{\mathrm{T}}$ and M. psychrotolerans $\mathrm{M} 13-2^{\mathrm{T}}$.

The novel marine, heterofermentative, lactic-acid strain belongs to the genus Marinilactibacillus on the basis of its 16S rRNA gene sequence (V6 region) and some phenotypic characteristics. However, DNA-DNA hybridization studies showed that its closest phylogenetic relative, M. psychrotolerans, could not be assigned to the same species $(<20 \%)$ (Stackebrandt \& Goebel, 1994).

Strain $\mathrm{LT} 20^{\mathrm{T}}$ differs from M. psychrotolerans in its optimum ranges for $\mathrm{pH}$ and $\mathrm{NaCl}$ concentration. Strain LT20 ${ }^{\mathrm{T}}$ can also be distinguished from $M$. psychrotolerans by the positive catalase reaction and $\beta$-galactosidase activity and by acetoin production. Tests for arginine dihydrolase, lysine decarboxylase, ornithine decarboxylase, gelatinase, urease, tryptophan deaminase and $\mathrm{H}_{2} \mathrm{~S}$ production from thiosulfate were negative and indole was not produced. Fermentation of sugars by strain LT $20^{\mathrm{T}}$ was also slightly different from that of $M$. psychrotolerans (see the supplementary tables available in IJSEM Online). Strain LT20 ${ }^{\mathrm{T}}$ differs from strain $\mathrm{M} 13-2^{\mathrm{T}}$ in the PLFA distribution pattern.

Most obvious is the shift from chain lengths of 14 and 16 carbon atoms $\left(\mathrm{LT} 20^{\mathrm{T}}\right)$ to 16 and 18 carbon atoms $\left(\mathrm{M} 13-2^{\mathrm{T}}\right.$ ), and especially the high abundance of $\mathrm{C}_{18: 1}$ in $\mathrm{M} 13-2^{\mathrm{T}}$ (Table 1). At first sight, this difference implies different responses by these species to high pressure and to low temperature in order to maintain membrane fluidity with regard to the phase transition temperature.

From the above results, we conclude that strain LT20 ${ }^{\mathrm{T}}$ represents a novel Marinilactibacillus species. We propose to give it the name Marinilactibacillus piezotolerans sp. nov. to reflect its deep marine origin and its growth under a range of hydrostatic pressures.

\section{Description of Marinilactibacillus piezotolerans sp. nov.}

Marinilactibacillus piezotolerans (pie.zo.to'le.rans. Gr. v. piezo to press; L. part. adj. tolerans tolerating, N.L. part. adj. piezotolerans tolerating high hydrostatic pressure).

Gram-positive. Cells are non-spore-forming, non-motile rods, $2-2 \cdot 2 \times 0 \cdot 3-0 \cdot 35 \mu \mathrm{m}$. Facultative anaerobe. Grows between 4 and $50^{\circ} \mathrm{C}$, with optimum growth at around $37-40^{\circ} \mathrm{C}$; no growth is detected above $50^{\circ} \mathrm{C}$. Grows in $\mathrm{NaCl}$ concentrations ranging from 0 to $120 \mathrm{~g} \mathrm{l}^{-1}$, with the optimum at approximately $10-20 \mathrm{~g} \mathrm{l}^{-1}$; no growth detected at or above $130 \mathrm{~g} \mathrm{NaCl}^{-1}$. Grows at $\mathrm{pH}$ values between $5 \cdot 5$ and $10 \cdot 0$, with the optimum at around $\mathrm{pH} 7 \cdot 0-8 \cdot 0$. The optimum hydrostatic pressure for growth is $0 \cdot 1 \mathrm{MPa}$, with tolerance up to $30 \mathrm{MPa}$. Under optimal growth conditions (YPG medium, $37^{\circ} \mathrm{C}$, $\mathrm{pH} 7 \cdot 0$ and $20 \mathrm{~g} \mathrm{NaCl} \mathrm{l}^{-1}$ ), the doubling time is approximately $57 \mathrm{~min}$. Sulphate, thiosulphate, elemental sulphur, L-cystine, iron oxide, nitrate and nitrite are not reduced. The main components of the lipid complex of the cells are phosphatidylglycerols $(25 \%)$, diphosphatidylglycerols $(34 \%)$ and tentatively identified ammonium-containing phosphatidylserines (32\%); phosphatidylethanolamines are minor compounds, accounting for $9 \%$. The most abundant fatty acyl side chains (PLFAs) of these phospholipids are 16:0 and 14:0 and $16: 1$, while $14: 1$, cyclic $17: 0$ or $17: 1$, cyclic $19: 0$ or 19:1,12:0,18:0,18:1 and $15: 0$ are minor components (in decreasing intensity). Quinones are not detected. The $\mathrm{G}+\mathrm{C}$ content of the DNA of the type strain is $42 \cdot 0 \mathrm{~mol} \%$ (as determined by HPLC).

The type strain is $\operatorname{LT} 20^{\mathrm{T}}\left(=\right.$ DSM $\left.16108^{\mathrm{T}}=\mathrm{JCM} 12337^{\mathrm{T}}\right)$, which was isolated from deep sub-seafloor sediment.

\section{Acknowledgements}

The authors would like to thank the Ocean Drilling Program, Professor John Parkes and Dr Barry Cragg from Cardiff University for the Leg 190 samples. We acknowledge Dr Julian Marchesi (University of Cork) and Dr Jens Kallmeyer (Max Planck Institut für Marine Mikrobiologie, Bremen) for their help with sample handling and preparation. We also thank Dr Gordon Webster (Cardiff University) for helpful comments during preparation of this manuscript. L. T. would like to thank Dr Alexander Slobodkin for iron-reducing tests and Dr Katsuyuki Uematsu for assistance with preparation of electron micrographs. This work was funded by the European Union project DeepBUG (contract number EVK3-CT-1999-017). This research used samples and data provided by the Ocean Drilling Program, which is sponsored by the US National Science Foundation and participating countries under the management of Joint Oceanographic Institutions, Inc.

\section{References}

Bale, S. J., Goodman, K., Rochelle, P. A., Marchesi, J. R., Fry, J. C., Weightman, A. J. \& Parkes, R. J. (1997). Desulfovibrio profundus sp. nov., a novel barophilic sulfate-reducing bacteria from deep sediment layers in the Japan Sea. Int J Syst Bacteriol 47, 515-521. 
Cashion, P., Holder-Franklin, M. A., McCully, J. \& Franklin, M. (1977). A rapid method for the base ratio determination of bacterial DNA. Anal Biochem 81, 461-466.

Cragg, B. A., Bale, S. J. \& Parkes, R. J. (1992a). A novel method for the transport and long term storage of cultures and samples in an anaerobic atmosphere. Lett Appl Microbiol 15, 125-128.

Cragg, B. A., Harvey, F. M., Fry, J. C., Herbert, R. A. \& Parkes, R. J. (1992b). Bacterial biomass and activity in deep sediment layers of the Japan Sea, Hole 798B. Proceedings of Ocean Drilling Program, Scientific Results, Leg 128, pp. 761-776. College Station, TX: Texas A\&M University.

Erauso, G., Charbonnier, F., Barbeyron, T., Forterre, P. \& Prieur, D. (1992). Preliminary characterization of a hyperthermophilic archaebacterium with a plasmid, isolated from a North Fiji Basin hydrothermal vent. C R Acad Sci 314, 387-393.

Felsenstein, J. (1981). Evolutionary trees from DNA sequences: a maximum-likelihood approach. J Mol Evol 17, 368-376.

Felsenstein, J. (1985). Confidence limits on phylogenies: an approach using the bootstrap. Evolution 39, 783-791.

Franzmann, P. D., Höpfl, P., Weiss, N. \& Tindall, B. J. (1991). Psychrotrophic, lactic acid-producing bacteria from anoxic waters in Ace Lake, Antarctica; Carnobacterium funditum sp. nov. and Carnobacterium alterfunditum sp. nov. Arch Microbiol 156, 255-262.

Inagaki, F., Suzuki, M., Takai, K., Oida, H., Sakamoto, T., Aoki, K., Nealson, K. H. \& Horikoshi, K. (2003). Microbial communities associated with geological horizons in coastal subseafloor sediments from the Sea of Okhotsk. Appl Environ Microbiol 69, 7224-7235.

Ishikawa, M., Nakajima, K., Yanagi, M., Yamamoto, Y. \& Yamasato, K. (2003). Marinilactibacillus psychrotolerans gen. nov., sp. nov., a halophilic and alkaliphilic marine lactic acid bacterium isolated from marine organisms in temperate and subtropical areas of Japan. Int J Syst Evol Microbiol 53, 711-720.

Janssen, P. H., Evers, S., Rainey, F. A., Weiss, N., Ludwig, W., Harfoot, C. G. \& Schink, B. (1995). Lactosphaera gen. nov., a new genus of lactic acid bacteria, and transfer of Ruminococcus pasteurii Schink 1984 to Lactosphaera pasteurii comb. nov. Int J Syst Bacteriol 45, 565-571.

Jeanthon, C., L'Haridon, S., Cueff, V., Banta, A., Reysenbach, A.-L. \& Prieur, D. (2002). Thermodesulfobacterium hydrogeniphilum sp. nov., a thermophilic, chemolithoautotrophic, sulfate-reducing bacterium isolated from a deep-sea hydrothermal vent at Guaymas Basin, and emendation of the genus Thermodesulfobacterium. Int J Syst Evol Microbiol 52, 765-772.

Jukes, T. H. \& Cantor, C. R. (1969). Evolution of protein molecules. In Mammalian Protein Metabolism, vol. 3, pp. 21-132. Edited by H. N. Munro. New York: Academic Press.

Kato, C., Sato, T. \& Horikoshi, K. (1995). Isolation and properties of barophilic and barotolerant bacteria from deep-sea mud samples. Biodivers Conserv 4, 1-9.

Koroleff, F. (1969). Direct determination of ammonia in natural waters as indophenol blue. In Information on Techniques and Methods for Seawater Analysis, pp. 19-22. Charlottenlund: International Council for the Exploration of the Sea.

Lake, J. A. (1987). A rate-independent technique for analysis of nucleic acid sequences: evolutionary parsimony. Mol Biol Evol 4, 167-191.

Ludwig, W., Strunk, O., Westram, R. \& 29 other authors (2004). ARB: a software environment for sequence data. Nucleic Acids Res 32, 1363-1371.
Maidak, B. L., Cole, J. R., Lilburn, T. G. \& 7 other authors (2001). The RDP-II (Ribosomal Database Project). Nucleic Acids Res 29, 173-174.

Marteinsson, V. T., Watrin, L., Prieur, D., Caprais, J.-C., Raguénès, G. \& Erauso, G. (1995). Phenotypic characterization, DNA similarities, and protein profiles of twenty sulfur-metabolizing hyperthermophilic anaerobic archaea isolated from hydrothermal vents in the Southwestern Pacific Ocean. Int J Syst Bacteriol 45, 623-632.

Mesbah, M., Premachandran, U. \& Whitman, W. B. (1989). Precise measurements of the $\mathrm{G}+\mathrm{C}$ content of deoxyribonucleic acid by high-performance liquid chromatography. Int $J$ Syst Bacteriol 39, 159-167.

Mikucki, J. A., Liu, Y., Delwiche, M., Colwell, F. S. \& Boone, D. R. (2003). Isolation of a methanogen from deep marine sediments that contain methane hydrates, and description of Methanoculleus submarinus sp. nov. Appl Environ Microbiol 69, 3311-3316.

Moore, G. F., Taira, A., Klaus, A. \& 23 other authors (2001). Deformation and fluid flow processes in the Nankai Trough accretionary prism sites 1173-1178. In Proceedings of Ocean Drilling Program, Initial Reports, vol. 190. College Station, TX: Texas A\&M University.

Newberry, C. J., Webster, G., Cragg, B. A., Parkes, R. J., Weightman, A. J. \& Fry, J. C. (2004). Diversity of prokaryotes and methanogenesis in deep subsurface sediments from the Nankai Trough, Ocean Drilling Program Leg 190. Environ Microbiol 6, 274-287.

Ntougias, S. \& Russell, N. J. (2001). Alkalibacterium olivoapovliticus gen. nov., sp. nov., a new obligately alkaliphilic bacterium isolated from edible-olive wash-waters. Int $J$ Syst Evol Microbiol 51, 1161-1170.

Parkes, R. J., Cragg, B. A., Bale, S. J., Goodman, K. \& Fry, J. C. (1995). A combined ecological and physiological approach to studying sulphate reduction within deep marine sediment layers. J Microbiol Methods 23, 235-249.

Parkes, R. J., Cragg, B. A. \& Wellsbury, P. (2000). Recent studies on bacterial populations and processes in subseafloor sediments: a review. Hydrogeol J 8, 11-28.

Radke, M., Sittardt, H. G. \& Welte, D. H. (1978). Removal of soluble organic matter from rock samples with a flow-through extraction cell. Anal Chem 50, 663-665.

Rhee, S. K. \& Pack, M. Y. (1980). Effect of environmental pH on fermentation balance of Lactobacillus bulgaricus. J Bacteriol 144, 217-221.

Saitou, M. \& Nei, M. (1987). The neighbor-joining method: a new method for reconstructing phylogenetic trees. Mol Biol Evol 4, 406-425.

Slobodkin, A. I., Tourova, T. P., Kuznetsov, B. B., Kostrikina, N. A., Chernyh, N. A. \& Bonch-Osmolovskaya, E. A. (1999). Thermoanaerobacter siderophilus sp. nov., a novel dissimilatory Fe(III)-reducing anaerobic thermophilic bacterium. Int $J$ Syst Bacteriol 49, 1471-1478.

Solorzano, L. (1969). Determination of ammonia in natural waters by the phenol-hypochlorite method. Limnol Oceanogr 14, 799-801.

Spielmeyer, W. K., McMeekin, T. A., Miller, J. M. \& Franzmann, P. D. (1993). Phylogeny of the Antarctic bacterium, Carnobacterium alterfundicum. Polar Biol 13, 501-503.

Stackebrandt, E. \& Goebel, B. M. (1994). Taxonomic note: a place for DNA-DNA reassociation and 16S rRNA sequence analysis in the present species definition in bacteriology. Int J Syst Bacteriol 44, 846-849. 
Tamaoka, J. \& Komagata, K. (1984). Determination of DNA base composition by reversed-phase high-performance liquid chromatography. FEMS Microbiol Lett 25, 125-128.

Toffin, L., Webster, G., Weightman, A. J., Fry, J. C. \& Prieur, D. (2004a). Molecular monitoring of culturable bacteria from deep-sea sediment of the Nankai Trough, Leg 190 Ocean Drilling Program. FEMS Microbiol Ecol 48, 357-367.

Toffin, L., Bidault, A., Pignet, P., Tindall, B. J., Slobodkin, A., Kato, C. \& Prieur, D. (2004b). Shewanella profunda sp. nov., isolated from deep marine sediment of the Nankai Trough. Int J Syst Evol Microbiol 54, 1943-1949.

Wery, N., Moricet, J. M., Cueff, V., Jean, J., Pignet, P., Lesongeur, F., Cambon-Bonavita, M. A. \& Barbier, G. (2001). Caloranaerobacter azorensis gen. nov., sp. nov., an anaerobic thermophilic bacterium, isolated from a deep-sea hydrothermal vent. Int J Syst Evol Microbiol 51, 1789-1796.

White, D. C., Davies, W. M., Nickels, J. S., King, J. D. \& Bobbie, R. J. (1979). Determination of the sedimentary microbial biomass by extractable lipid phosphate. Oecologia 40, 51-62.

Widdel, F. \& Bak, F. (1992). Gram-negative mesophilic sulfatereducing bacteria. In The Prokaryotes, 2nd edn, pp. 3352-3378. Edited by A. Balows, H. G. Trüper, M. Dworkin, W. Harder \& K. H. Schleifer. New York: Springer.

Zink, K.-G., Wilkes, H., Disko, U., Elvert, M. \& Horsfield, B. (2003). Intact phospholipids - microbial "life markers" in marine deep subsurface sediments. Org Geochem 34, 755-769. 